УДК 811.111-26.019

DOI https://doi.org/10.26661/2414-1135-2021-84-4

\title{
ЗАСОБИ ЕКСПРЕСІЇ В АНГЛОМОВНОМУ НАУКОВО-ПОПУЛЯРНОМУ ТЕКСТІ Й ШЛЯХИ ЇЇ ВІДТВОРЕННЯ В УКРАЇНСЬКОМОВНОМУ ПЕРЕКЛАДІ
}

\author{
Бондарчук О. В. \\ студентка II курсу магістратури \\ факультету лінгвістики \\ Національний технічний університет Украӥни \\ «Київський політехнічний інститут імені Ігоря Сікорського» \\ просп. Перемоги, 37, Київ, Україна \\ orcid.org/0000-0002-3049-8503 \\ bondarchuk0302@gmail.com \\ Воробйова О. П. \\ доктор філологічних наук, професор, \\ професор кафедри теорії, практики та перекладу англійської мови \\ факультету лінгвістики \\ Національний технічний університет Украӥни \\ «Киїський політехнічний інститут імені Ігоря Сікорського» \\ просп. Перемоги, 37, Київ, Украӥна \\ orcid .org/0000-0001-9039-9737 \\ o.p.vorobyova@gmail.com
}

\begin{abstract}
Ключові слова: науковопопулярний текст, категорія експресивності, емотивність, емоичійно-оичінна лексика, емотив, иляхи перекладу.
\end{abstract}

Статтю присвячено розгляду лінгвальних засобів вираження експресивності в англомовному науково-популярному тексті та розкриттю шляхів їх відтворення в українськомовному перекладі. У статті доведено, що саме експресивність становить одну із основних відмінностей науковопопулярного тексту від власне наукового. Описано функції засобів вираження експресивності в науково-популярному творі «Та ви жартуєте, містере Фейнман!: Пригоди допитливого дивака» Р. Фейнмана. 3'ясовано особливості перекладу емотивної лексики та інших емотивів як різнорівневих мовних і мовленнєвих одиниць на позначення й вираження емоцій як засобів забезпечення експресії науково-популярного тексту. Підвищена експресивність науково-популярного тексту, причини якої мають змістовий і комунікативно-прагматичний характер, забезпечується, поряд із засобами емотивності, використанням великої кількості пояснень, лексичних повторів та акцентованою орієнтацією на потенційного читача. Подвійна мета науковопопулярного тексту-донести до читача пізнавальнуінформацію та одночасно захопити його цією інформацією - тягне за собою його полемічність, яка передбачає наявність експресії й оцінності. Експресивні елементи сприяють посиленню аргументованості, полегшують сприйняття і розуміння найбільш складних фрагментів тексту, що містять нові ідеї і поняття. Експресивність - це властивість тексту або частини тексту, що передає зміст зі збільшеною інтенсивністю і має своїм результатом емоційне або логічне посилення. Специфіка експресивності науково-популярних текстів полягає у тому, що вона орієнтована на діалог між адресатом і адресантом у контексті емоційно навантаженого прагматичного впливу. Переклад експресивно забарвленої емотивної лексики та інших емотивів полягає у націленості на максимально повне відтворення засобами мови, поряд із пізнавально-раціональною, й емоційної інформації з метою досягнення аналогічного прагматичного впливу на читача перекладеного тексту. 


\title{
EXPRESSIVE MEANS IN ENGLISH POPULAR SCIENCE TEXTS AND WAYS OF THEIR TRANSLATION INTO UKRAINIAN
}

\author{
Bondarchuk O. V. \\ 2-nd year Master Student \\ Faculty of Linguistics \\ National Technical University of Ukraine \\ "Igor Sikorsky Kyiv Polytechnic Institute" \\ Peremohy Ave., 37, Kyiv, Ukraine \\ orcid.org/0000-0002-3049-8503 \\ bondarchuk0302@gmail.com \\ Vorobyova O. P. \\ Doctor of Philological Sciences, Professor, \\ Professor at the Department of Theory, Practice and Translation of English \\ Faculty of Linguistics \\ National Technical University of Ukraine \\ "Igor Sikorsky Kyiv Polytechnic Institute" \\ Peremohy Ave., 37, Kyiv, Ukraine \\ orcid.org/0000-0001-9039-9737 \\ o.p.vorobyova@gmail.com
}

Key words: popular science text, category of expressiveness, emotivity, emotional and evaluative vocabulary, ways of translation.
This paper addresses the issue of expressive linguistic means in English popular science (pop-sci) texts as well as the ways of their translation into Ukrainian. The paper proves that expressiveness is one of the main features that differentiate popular science texts from scientific texts proper. The paper describes the functions of expressive means in the pop-sci book "Surely you're joking, Mr. Feynman!: Adventure of a curious Character" by R.P. Feynman. The research highlights the specificity of translating the emotional vocabulary and other emotives as multilevel language and speech units used to denote and manifest emotions as those that provide expressiveness of pop-sci. Accentuated expressiveness of pop-sci texts, provoked by both their content and pragmatics, is reached, along with emotively charged elements, by the use of numerous explanations, lexical repetitions, and the emphatic focus on the potential reader. The double objective of the popular science text, i.e. to convey cognitive information to the reader while capturing him/her with this information, leads to the polemic nature of such texts, which is the reason for their expressivity and the presence of evaluation. Expressive elements help to strengthen the argumentation, facilitate the perception and understanding of the most intricate contexts that contain new ideas and concepts. Expressiveness is a property of text or its part that conveys meaning with increased intensity and results in an emotional or logical reinforcement. The specificity of pop-sci texts expressiveness is in its dialogical orientation in the context of emotionally charged pragmatic impact. The translation of expressively marked emotional vocabulary and other emotives consists is aimed to fully convey by means of target language not only cognitively rational but also emotional information, in order to exercise a similar pragmatic impact on the target reader. 
Постановка проблеми. Сучасна наука інтенсивно розвивається, і більшість наукових праць пишуться англійською мовою. Науково-популярні тексти виступають провідниками між закритим незрозумілим науковим світом та широким загалом. Тому переклад науково-популярних текстів $\epsilon$ важливим способом передачі накопичених знань як фахівцям, так і людям, які не мають глибоких знань у науковій сфері.

Аналіз сучасних критичних видань показує, що сфера перекладу науково-популярних текстів $€$ малодослідженою, а питання перекладу мовних засобів вираження експресивності взагалі залишилося поза увагою українських перекладознавців, що складає актуальність цієї роботи.

Отже, мета дослідження полягає у з'ясуванні мовних засобів вираження експресивності в науково-популярному тексті, а саме відомій книзі американського фізика, Нобелівського лавреата, Річарда Фейнмана "Surely You're Joking, Mr. Feynman!: Adventures of a Curious Character" [12], та з'ясуванні шляхів їх відтворення в українськомовному перекладі - «Та ви жартуєте, містере Фейнман!: Пригоди допитливого дивака» (переклад М. Климчук) [9]. Для досягнення мети необхідно вирішити низку завдань: розглянути науково-популярний текст та довести, що експресивність становить одну з основних відмінностей від наукового тексту; описати функціонування експресивності в науково-популярному тексті; з'ясувати особливості перекладу емотивної лексики та інших мовних одиниць на позначення й вираження емоцій.

Об'сктом наукової роботи виступають мовні засоби вираження експресивності в науково-популярному тексті.

Предметом дослідження $\epsilon$ шляхи відтворення мовних засобів вираження експресивності в науково-популярному тексті під час перекладу.

Виклад основного матеріалу дослідження. У сучасній стилістиці питання про статус науково-популярного типу мовлення в системі функціональних стилів не вирішене остаточно. Багато лінгвістів розглядають науково-популярний текст у межах наукового функціонального стилю як його підстиль. Науковий функціональний стиль $\mathrm{i}$ науково-популярний підстиль, на думку цих вчених, об'єднує між собою єдина цільова установка, загальна комунікативна задача - повідомлення наукових знань.

Науково-популярний текст - це підстиль наукового стилю, що відрізняється від суто наукових текстів завданнями і метою спілкування, характером взаємовідносин між автором і читачем, а також вмістом [5, с. 137-140].

Як у власне науковому, так і в науково-популярному творі присутні загальнонаукова лексика i терміни. Однак автор науково-популярного тексту зазвичай показує готовий результат дослідження, при цьому опускається велика частина логічних доказів і аргументації, щоб зробити текст i доступним, і захоплюючим, оскільки науково-популярний текст покликаний вирішити специфічну комунікативну задачу - повідомити неспеціалісту перевірені наукові знання.

3 іншого боку, науково-популярний текст - це окремий тип тексту, що відрізняється від власне наукового підвищеною експресивністю шляхом використання великої кількості пояснень, лексичних повторів та орієнтацією на потенційного читача. Завдання науково-популярного тексту - донести до читача пізнавальну інформацію та одночасно захопити його цією інформацією.

Як зазначає I.C. Алексєєва, в науково-популярному тексті фахівець представляе свою науку, i відомості, які він повідомляє, вірогідні та об'єктивні. Але всю міру своєї компетентності він не може проявити, оскільки читачем (аудиторією) $є$ малокомпетентний реципієнт. Знімаються і вікові обмеження: велика кількість науково-популярних текстів призначається дітям і підліткам. Те, яким способом автор пристосовує інформацію до сприйняття некомпетентним реципієнтом, залежить від автора [1, с. 271].

Науково-популярний текст містить великий обсяг когнітивної інформації. Діапазон засобів, за допомогою яких вона передається, нагадує відповідний арсенал наукового і науково-навчального текстів. Але під час аналізу ми стикаємося як 3 якісними, так і з кількісними відмінностями.

Полемічність науково-популярних текстів $\epsilon$ причиною наявності в них експресії й оцінки. Експресивні елементи сприяють посиленню аргументованості висловлювання, полегшують сприйняття і розуміння найбільш складних аспектів. Інша причина використання експресивних елементів у науковій прозі - це відсутність у мові відповідних понять для вираження нових ідей. Слід зазначити, що центром мовної системи в науковому стилі є синтаксичні засоби.

Експресивність - це властивість тексту або частини тексту, що передає зміст зі збільшеною інтенсивністю і має своїм результатом емоційне або логічне посилення, яке може бути чи не бути подібним. Матеріал дослідження показує, що в науковому-популярному тексті експресивність це далеко не рідкісне явище, що володіє певною специфікою. Використання специфічних експресивних засобів свідчить про наявність діалогу між адресатом і адресантом.

Категорія експресивності нерозривно пов'язана 3 категорією емоційності, яка тлумачиться в літературі неоднозначно - як функціональна та мовна. Відсутність єдиного трактування категорії 
експресивності призводить до того, що лінгвісти розмежовують емоційність і експресивність на різних підставах. Точки зору вчених на співвідношення цих термінів коливаються від їх ототожнення до чіткої диференціації. Так, наприклад, Т.В. Матвєєва, В.К. Харченко та інші вважають поняття емоційності та експресивності практично синонімами. Т.В. Матвєєва зазначає, що «експресивне слово 3 параметрично-оцінним компонентом конотації - це фактично емоційно-оцінне слово» [4, с. 15].

B.I. Шаховський вважає експресивність і емоційність частково подібними, але автономними явищами i допускає існування неекспресивної емоційності. Відповідно до думки цього автора емоційність висловлювання завжди пов'язана 3 реалізацією емоційної оцінки, тоді як експресивність частіше пов'язана 3 інтелектуальним наміром переконати у чомусь адресата [11, с. 3-25].

В.Н. Цоллер переконує, що основна відмінність експресивності від емоційності полягає у тому, що як компонент конотації вона відіграє другорядну роль порівняно з емоційністю, яка займає чільне місце. Експресивність, на думку науковця, «сприяє вираженню за допомогою незвичайного засобу емоційно-оцінного ставлення до того чи іншого явища дійсності, кращому донесенню логічної та емоційно-оцінної інформації до перцепієнта» [10, с. 64].

Ю.М. Осіпов наводить аргументи, згідно 3 якими поняття емоційності та експресивності не можуть зіставлятися ні як рівні, ні як різні за обсягом [6, с. 125-126]. Вчений підкреслює, що ці поняття не взаємозамінні, тому що перебувають у відношенні додатковості один до одного і співвідносяться як величина та функція. Емоційність становить компонент значення слова і тому є елементом мовної системи, а експресивність не входить до значення слова, тому що виникає у результаті вживання мовних одиниць і тому $є$ функціональною категорією. Аналогічної точки зору дотримується П.М. Панічєва. На їі думку, емоційність співвідноситься 3 пізнавально-відбивною функцією мислення, а експресивність - 3 дієвою. Відповідно, емоційність і експресивність виконують різні функціональні завдання. Основною функцією експресивної одиниці є вплив на реципієнта (прагматична), а емотивної - функція емоційного самовираження продуцента. Якщо емоційні елементи використовуються для вираження суб'єктивного ставлення і для впливу на почуття інших, то експресивні - для посилення виразності під час вираження емоцій, волі, думки. Подібність емоційності та експресивності полягає в їх «інтелектуальній опосередкованості» [7, с. 9-10].

Слід зазначити, що найбільш поширеною та правомірною є точка зору, згідно з якою експресив- ність й емоційність не можна об'єднувати в одне поєднане поняття. В основі цього підходу лежать погляди, сформульовані С.М. Галкіною-Федорук. На іiі переконання, поняття «експресивність» за змістом ширше за поняття «емоційність», тому що вираження емоцій у мові завжди експресивне, але експресивність в мові не завжди емоційна. Дослідниця також вважає, що експресивні мовні засоби підсилюють виразність і зображальність як під час опису емоцій, так і під час вираження думки [3, с. 107-108].

Що ж стосується співвідношення термінів «емоційність» і «експресивність», то слід виходити 3 того, що, висловлюючи емоційне ставлення до того чи іншого явища, мовець завжди використовує експресивні (виразні, образотворчі) мовні засоби. Однак експресивність у мові не завжди емоційна, тому що експресивні мовні засоби підсилюють виразність не тільки під час емоційного впливу, але і під час вираження думки. Таким чином, емоційність і експресивність - дві тісно взаємопов'язані, але не тотожні категорії. Поняття «експресивність» за змістом ширше за поняття «емоційність».

Підсумовуючи вищесказане, зазначимо, що емоційність та експресивність - це два терміни, які позначають одне явище - людські почуття, але в різних площинах. Так, емоційність - це психологічна категорія, а емотивність - мовна. Емоційність показує психічний стан людини, тоді як емотивність - це вербальне вираження емоцій мовця [2, c. 165-174].

Що стосується передачі емоційно-оцінного змісту слова, то необхідно встановити, чи поширюється воно на все речення або ж не виходить за межі слова [7, с. 57]. У першому разі можливе відтворення емоційно-оцінного змісту нелокального: "I jumped out of bed yelling, "It worked! It worked!” [12, p. 5]. // «Я радісно скочив з ліжка: «Ура! Працює!» [9, с. 16].

Так, цілих два речення зазнали трансформацій, але із збереження головної мети - передачі позитивної емоції (у нашому разі захвату) повною мірою.

У другому - збереження емоційного компонента в лексичній одиниці обов'язкове: “When my mother and father went out until late at night, they would come into my room and take the earphones off and worry about what was going into my head while I was asleep" [12, p. 5].// «Повернувиись пізно ввечері додому, батьки заглядали в мою кімнату, знімали з мене навушники і все переживали, щзо діється в моїй голові» [9, с. 16]. Тут єдине слово, яке показує емоцію, виражене дієсловом “to worry" і передано в українському перекладі словниковим відповідником - «пережсивати». 
Передача асоціативно-образної характеристики найлегше відбувається під час збігу в обох мовах цих компонентів. Складніше, якщо ці компоненти не збігаються. Зазвичай це стосується фразеологічного фонду, який у більшості випадків різниться в англійській та українській мовах. Так, наприклад, в аналізованій книзі бачимо певні розбіжності у фразеологізмах: "That particular time it happened to be a friend of my mother, so I had time there was nobody on my back saying, "What are you doing?” [12, p. 9]. // «На щзастя, ніхто не стояв над душею $і$ не казав: Що ти робиш?» [9, с. 21]. Тут англійський фразеологізм “be on sb's back”, означає «надокучати присутністю, невідступним переслідуванням тощо» (негативна емоція - роздратування). В українській мові існує частковий еквівалент «стояти над душею», де різняться назви місця: $b a c k \neq$ душа.

Передача значення похідного слова може йти шляхом лексичних втрат, але зі збереженням комунікативної адекватності. Розглянемо англійський прикметник “great”, який передається в українському перекладі різними лексемами: «класно/ потрясно»:

"But it was all right, and when the bulbs were in series, all halflit, they would gloooooooooow, very pretty - it was great! [12, p. 5]. // «Але все працювало: якщзо поєднати лампочки послідовно, вони загоралися на півсили і тлі-i-i-i-i-ли. Було дуже красиво - просто класно!» [9, с. 15].

"I would put a Raytheon RH tube, which had argon gas in it, across the terminals, and the spark would make a purple glow inside the vacuum it was just great!" [12, p. 5]. // «Брав аргонову лампу фірми "Рейтон», під'єднував їі в ланцңюг, $і$ вона світилася пурпуровим кольором - просто потрясло!» $[9$, с. 16].

Еквівалентність на рівні висловлювання може передаватися власне висловлюванням, незалежно від змісту одиниць, які входять до нього, i, власне, поєднанням одиниць. В обох випадках важливу роль відіграють синтаксичні структури, вибір яких залежить від ситуації та правил вживання, порядку проходження елементів висловлювання. В англійській мові фіксований порядок слів, саме тому інверсія використовується як ефективний спосіб емоційної характеристики. В українській мові 3 iіi нефіксованим порядком слів інверсія недостатньо дієва для вираження емоційності, в цих випадках до неї додають спеціальні слова та словосполучення: "He got me other jobs, and kept telling everybody what a tremendous genius I was" [12, p. 8]. // «Він кликав мене ремонтувати й інші речі і всім розповідав, щуо я геній» [9, с. 2].

Еквівалентність на рівні повідомлення залежить від способів опису ситуації, викладу думки, тобто спирається на позалінгвістичні чинники.
Так, у різних ситуаціях можна виявити більш $\mathrm{i}$ менш суворий набір повідомлень, наприклад, вираження здивування в англійській мові My God! [12, p. 8], українською буде Боже ти мій... [9, с. 20] - і це суворо закріплено. Саме ідентичність ситуації $є$ критерієм правильності вибору повідомлення в перекладі.

Еквівалентність мети комунікації включає в першу чергу інформацію про мету комунікації, оскільки повідомлення породжується 3 метою передати певну інформацію, почуття, емоційний настрій, ставлення, саме ця мета і повинна бути збережена в перекладі. Йдеться вже не про емоційність окремого знака, а про емоційність всього висловлювання. Мета комунікації для встановлення еквівалентності оригіналу та перекладу може превалювати над усіма іншими рівнями шляхом відмови відтворення змісту на інших рівнях.

Отже, текст перекладу повинен відповідати таким вимогам: бути еквівалентним початковому тексту в комунікативно-функціональному відношенні; бути в максимально можливій мірі семантико-структурним аналогом вихідного тексту; не містити «компенсуючих» відхилень.

Досягнення еквівалентності у перекладі висловлювання 3 прагматичної точки зору завдання першорядне, оскільки ідентичний комунікативний ефект дозволяє зробити на читача відповідне оригіналу враження.

Реалізація емоційної інтенції безпосередньо залежить від обраних автором висловлювання лексичних одиниць, таким чином, еквівалентний переклад емоційно-оцінних одиниць безпосередньо пов'язаний з реалізацією ілокутивної функції висловлювання в перекладі.

Висновки і перспективи подальших розробок. На основі цього ми переконуємось у тому, що переклад емотивної лексики полягає у максимально повній передачі емоційної інформації засобами мови $з$ метою створення того ж прагматичного впливу на реципієнта, який надає вихідний текст на читача тексту-оригіналу. Прагматичний вплив на одержувача - це основна функція категорії емотивності.

Перспективою подальших досліджень є поглиблене дослідження перекладу мовних засобів вираження експресивності в науково-популярному тексті.

\section{ЛІТЕРАТУРА}

1. Алексеева И.С. Введение в переводоведение. Санкт-Петербург : Издательский центр «Академия» 2004. 352 с.

2. Воробйова, О.П., \& Гладьо С.В. (2001). The pragmatics of emotivity markers in literary discourse: Cognitive implications. 
Науковий Вісник кафедри ЮНЕСКО КДЛУ, 2001. C.165-174.

3. Галкина-Федорук Е. М. Об экспрессии и эмоциональности в языке. Сборник статей по языкознанию. Москва: Наука, 1958. C. $103-124$.

4. Матвеева Т.В. Лексическая экспрессивность в языке. Свердловск : УрГУ, 1986. 92 с.

5. Орешич Ю.С. Науково-популярний текст: до проблеми визначення. Нова філологія. 2017. №. 70. C. 137-140.

6. Осипов Ю.М. Об уточнении понятия «эмоциональность» как лингвистического термина. Учен. зап. МГПИ В. И. Ленина. Проблемы синтаксиса английского языка. 1970. № 422. C. 116-127.

7. Паничева П.Н. Структурно-семантические и прагматические характеристики восклицательных предложений в английской диалогической речи : автореф. дис. ... канд. филол. наук. Ставрополь, 2004. $21 \mathrm{c}$.

8. Стаценко А.С. Некоторые трудности перевода эмоциональной лексики с английского языка на русский. Кониепт. 2014. №. 4. С. 56-60.

9. Фейнман Р. Та ви жартуєте, містере Фейнман! Пригоди допитливого дивака / пер. 3 англ. Микола Климчук. Київ : Наш формат, 2018. $400 \mathrm{c.}$

10. Цоллер В.Н. Экспрессивная лексика: семантика и прагматика. Филологические науки. 1996. № 6. С. 62-71.

11. Шаховский В.И. Категоризация эмоций в лексико-семантической системе языка. Воронеж : Изд-во Воронежского университета, 1987. $192 \mathrm{c}$.

12. Feynman R.P. Surely you're joking, Mr. Feynman! (Adventure of a curious Character. WW. Norton Company, Inc., 1985. 205 p.

\section{REFERENCES}

1. Alekseeva I.S. (2004) Introduction to translation studies [Vedeniye $\mathrm{v}$ perevodovedeniye]. $\mathrm{SPb}$. : Publishing Center "Academy". 352 p.

2. Vorobiova, O. P., \& S. V. Hlado. (2001). The pragmatics of emotivity markers in literary discourse: Cognitive implications. Naukovyi Visnyk kafedry YUNESKO KDLU, 2001. Pp. 165-174.
3. Galkina-Fedoruk E.M. (1958) On expression and emotionality in language [Ob ekspresii $\mathrm{s}$ emotsionalnosti v yazyke]. Collection of articles on linguistics. Moscow: Science. Pp. 103-124.

4. Matveeva T.V. (1986) Lexical expressiveness in language [Leksicheskaya ekspresivnost $\mathrm{v}$ yazyke]. Sverdlovsk: UrGU. 92 p.

5. Oreshich Yu.S. (2017) Popular science text: before the problem of value [Naukovopopulyarnij tekst: do problemy vyznachennya]. Nova filologiya. 2017. Vol. 70. Pp. 137-140.

6. Osipov Yu. M. (1970) On the clarification of the concept of "emotionality" as a linguistic term [Ob utochnenii ponyatiya "emotsionalnost" kak lingvisticheskogo termina]. Uchenye zapiski MGPI V.I. Lenina. English syntax problems. Vol. 422. Pp. 116-127.

7. Panicheva P.N. (2004) Structural-semantic and pragmatic characteristics of exclamation sentences in English dialogical speech [Struktunro-semanticheskie i pragmaticheskie harakteristiki vosklicatelnyh predlozhenij $\mathrm{v}$ anglijskoj dialogicheskoj rechi]: author. dis. ... cand. philol. sciences. Stavropol. 21 p.

8. Statsenko A.S. (2014) Some difficulties in translating emotional vocabulary from English into Russian [Nekotorye trudnosti perevoda emotionalnoj leksiki s anglijskogo yazyka na ruskij]. Kontsept. Vol. 4. Pp. 56-60.

9. Feynman R. (2018) Surely you're joking, Mr. Feynman! Adventure of a curious Character. Та ви жартуєте, містере Фейнман! Пригоди допитливого дивака [Ta vy zhartuyete, mistere Feyman! Prygody dopytlyvogo dyvaka]. / Translate from English by Mykola Klimchuk. Kyiv: Nash format, 2018. 400 p.

10. Tsoller V.N. (1996) Expressive vocabulary: semantics and pragmatics [Ekspresivnaya leksika i pragmatika]. Filologicheckiye nauki. Vol 6. Pp. 62-71.

11. Shakhovsky V.I. (1987) Categorization of emotions in the lexical-semantic system of the language [Kategorazatsiya emotsij v leksikosematicheskoj sisteme yazyka]. Voronezh : Voronezh University Publishing House. 192 p.

12. Feynman R.P. (1985) Surely you're joking, Mr. Feynman! Adventure of a curious Character. WW. Norton Company, Inc. 205 p. 